\title{
THE CONCEPT OF “LANDISATION" OF POLAND. SELECTED ASPECTS
}

Piotr Sobański

Dr., LLM, an Attorney at law of District Bar Association in Zielona Góra, master of laws, an Assistant professor at the Faculty of Law and Administration of the University of Zielona Góra

9 Słowiański pl., 65-069 Zielona Gora, Poland https://orcid.org/0000-0001-8303-1125 piotr.sobanski@adwokatura.home.pl

\begin{abstract}
The article analyzes the issues related to the possibility of leading to the landisation of Poland. The landisation should be understood as the process of transformation of Poland into a federal state. The Republic of Poland is a unitary state. The territorial system of the Republic of Poland ensures the decentralization of public authority, which should not be seen as a possibility of introducing a federal system. The provisions on local selfgovernment existing in Poland are fully compliant with the European Charter of Local SelfGovernment.
\end{abstract}

Keywords: decentralization, the European Charter of Local Self-Government, federalisation, landisation, the Constitution of the Republic of Poland

\section{INTRODUCTORY REMARKS}

The basis for considering the so-called landisation is the content of the 21 SelfGovernmental Theses of June 4, 2019. This topic is current and very significant, because a part of Polish society is afraid of possibility of landisation of Polish state (Lewandowski, 2019; Rachoń, 2019). In this context, landisation should be perceived as a process of gradual transformation of Poland into a federal state, such as Germany.

On June 4, 2019, during the celebration of Freedom and Solidarity in Gdańsk, over 300 city presidents, mayors, starosts and marshals discussed the future of Polish towns and villages. The result of the findings was a declaration containing 21 Theses. The Theses were presented as postulates of the Self-Governing Republic of Poland on August 31, 2019 during the debate "The Future of Self-Government" at the European Solidarity Center in Gdańsk. The self-governing Republic of Poland has declared that it will prepare draft bills to enable a debate in Polish Parliament. The declaration of June 4, 2019 was an appeal for the decentralization of the state and the starting point for introducing solutions that strengthen local self-government (Sobański, 2020).

The carried out analysis of the postulates of the Self-Governing Republic of Poland is based mainly on the Constitution of the Republic of Poland and the European Charter of Local Self-Government. The Preamble to Theses contains the demand to "ensure the possibility of 
development (...) of cities and communes in accordance with the Constitution of the Republic of Poland and the European Charter of Local Self-Government". The deliberations relate mainly to the following Theses: 1, 3, 5, 17.

The paper is the English (changed and completed) version of the paper "Wybrane aspekty prawne tzw. landyzacji Polski" (https://www.researchgate.net/publication/338753486 Wybrane aspekty prawne tzw landyzacji Polski). The paper was published under Creative Commons in January 2020.

\section{THE ISSUE OF UNITARITY AND DECENTRALIZATION IN THE LIGHT OF THE CONSTITUTION OF THE REPUBLIC OF POLAND}

According to the Article 3 of the Constitution, the Republic of Poland shall be a unitary State. The principle of unitarity indicates the homogeneous nature of Poland. This applies the territorial structure, the legal system and the socio-political structure. The unitarity of Poland expressly excludes a transformation into the federal system of the state (Kościelniak, 2012). Pursuant to the Article 15 Section 1 of the Constitution, the territorial system of the Republic of Poland shall ensure the decentralization of public power. However, the principle of state unitarity marks the limit of the principle of decentralization. Thus, non-centralized state administration and centralized government administration are homogeneous while respecting the separateness of both sectors (Korczak, 2016; Kościelniak, 2012; Patyra, 2017).

According to Art. 16 Section 2 of the Constitution, local government shall participate in the exercise of public power. The substantial part of public duties which local government is empowered to discharge by statute shall be done in its own name and under its own responsibility. The regulations contained in the Constitution provide for three basic principles relating to the functioning of local self-government. These are: the principle of subsidiarity, the principle of independence and the principle of the presumption of the competence of local self-government (Antkowiak, 2012). It should also be borne in mind that the goal of local government activities is responsibility for matters that directly applies to local communities and residents. According to the Article 4 Section 1 of the Constitution, supreme power in the Republic of Poland shall be vested in the Nation (Buzek, 2015). S. Patyra aptly notices that the best fulfillment of the idea of the sovereign power of the Nation within the meaning of the Article 4 Section 1 is the functioning of local communities (Patyra, 2018).

Not only state and government administration, but also local government administration is characterized by unitarity, of course with respect for its distinctiveness from the other two sectors (Korczak, 2016). The principle of unitarity shapes the systemic position of territorial self-government. The principle of unitarity also delimits the principle of decentralization, acting as a brake against the transformation of local self-government into territorial autonomy (Kościelniak, 2012).

While local self-government is an objective category and independent of the will of the legislator, its existence is shaped by respect for the common good. According to the Article 1 of the Constitution, Poland shall be the common good of all its citizens. The principle of the 
common good has not yet been legally defined (Kieres, 2015). W. Łączkowski aptly notices that the common good is one of the basic principles of social life, which should serve the entire community and its individual members (Łączkowski, 2018). The common good is therefore a collective and individual value at the same time. The will of the legislator determines the tasks of individual categories of local government. Units of local self-government do not have the powers of the legislative authority, and the administrative acts they adopt, both general and individual, must be anchored in the Constitution and statutes. Thus, the scope of competences of territorial self-government actually depends on the Parliament (Kościelniak, 2012; Litwin, 2018).

According to the Article 15 Section 2 of the Constitution, the basic territorial division of the State shall be determined by statute, allowing for the social, economic and cultural ties which ensure to the territorial units the capacity to perform their public duties. P. Radziewicz notes that under Art. 15 Section 2 of the Constitution, determining the meaning of the principle of decentralization falls within the competence of the legislator (Radziewicz, 2015). It corncerns a given area of social life, which is the subject of statutory regulations, as well as the subject of adopting detailed normative solutions in this respect. In this context, it should be emphasized that the principle of decentralization is clearly limited by Art. 3 of the Constitution, the principle of state unitarity.

To sum up, the principle of the common good in agreement with the principle of the unitarity of the state should be treated as factors that prevent the landisation of Poland without a radical change to the Constitution.

The Preamble to Theses contains the demand to "ensure the possibility of development (...) of cities and communes in accordance with the Constitution of the Republic of Poland". In Poland, there are a number of regulations relating to local government. The content of the Preamble seems to indicate that the regulations in force are not consistent with the Constitution. However, it should be remembered that in Poland exists the principle of presumption of constitutionality of statutes. This principle has not been regulated by law. There is an initial assumption that the laws passed are consistent with the provisions of the Constitution. The burden of proof rests on the entity who questions the compliance of the act with the Constitution. As long as the entity does not invoke convincing legal arguments to support its thesis, the Constitutional Tribunal recognizes the provisions of internal law under review as constitutional (Dąbrowski, 2017).

\section{THE LEGAL NATURE OF THE EUROPEAN CHARTER OF LOCAL SELF-GOVERNMENT}

On October 15, 1985, the European Charter of Local Self-Government was drawn up in Strasbourg. According to the Article 15 Section 1 of the Charter, the Charter is open for signature by the member states of the Council of Europe. The Charter was accepted and ratified by a number of European countries, including Poland. In the Preamble to the Charter it was argued that "the safeguarding and reinforcement oflocal self-government in the different European countries is an important contribution to the construction of a Europe based on the principles of democracy and the decentralisation of power". It was considered that "this entails the existence of local authorities endowed with democratically constituted decision-making 
bodies and possessing a wide degree of autonomy with regard to their responsibilities, the ways and means by which those responsibilities are exercised and the resources required for their fulfilment".

In Polish legal system, there has been a constitutional basis for local self-government, referred to in Article 2 of the Charter. According to Article 4 Section 1 of the Charter, the basic powers and responsibilities of local authorities shall be prescribed by the constitution or by statute. It should be emphasized that the will of the legislator determines the situation of self-government in the state. According to Article 4 Section 2 of the Charter, local authorities shall, within the limits of the law, have full discretion to exercise their initiative with regard to any matter which is not excluded from their competence nor assigned to any other authority.

The concept of local self-government was included in Article 3 of the Charter. Since the ratification of the Charter by Poland, there have been proposals to amend the existing provisions on local self-government. They are often justified by the necessity to adjust Polish legal system to the provisions of the Charter (Buczyński, Jaworski, Sosnowski, 2016; Mączyński, 2015). It is not, however, about whether or not these concepts are correct. The fundamental question arises as to how the Polish legislator is obliged by the regulations contained in the Charter to amend the existing provisions. When assessing the nature of the European Charter of Local Self-Government, it should be noted that, according to the jurisprudence of the Constitutional Tribunal, one cannot demand systemic changes in Poland consisting in the elimination of the principle of unitarity in favor of introducing a federal system. Pursuant to the Constitution, Polish local self-government meets the conditions for self-government adopted in the European Charter of Local Self-Government. Treating the principle of the unitarity of Poland as a threat to the existence of local government is also not justified (Kieres, 2015; Kościelniak, 2012). Moreover, as L. Kieres observes, the Constitutional Tribunal has repeatedly emphasized in the jurisprudence that the Preamble to the Charter refers to "wide degree autonomy" which is not identical to full autonomy (Kiees, 2015).

Digressively, in the jurisprudence of administrative courts there is a position that the European Charter of Local Self- Government is only a set of postulates. The postulates indicate the desired actions of the signatories for the purposes of the Preamble to the Charter. When analyzing the content of the regulations contained in the Charter, it is clear that they are formulated in a very general manner. It makes impossible to apply them directly (Sobański, 2020).

Therefore, the demand included in the Preamble to 21 Theses to ensure the possibility of the development of cities and communes in the manner referred to in the Theses cannot be effectively pursued on the basis of the European Charter of Local Self-Government. This also applies to any other proposed changes to the existing regulations that relate to both the shape and competences of local government in Poland. 


\section{CRITICAL REMARKS TO THE THESES OF THE SELF-GOVERNING REPUBLIC OF POLAND}

Thesis No. $5^{1}$ of the Self-Governing Republic of Poland states as follows: "The obligation to consult on all bills with representatives of local government and the local community". Argumentation of Thesis No. 5 provides information: "Bills, especially those relating to the own tasks of local government units, as defined in Article 166 of the Polish Constitution, should be subject to compulsory consultation with associations of local governments as representatives of local communities. The results of these consultations should be included in the regulatory impact assessment of each draft law on local communities. Failure to agree is the basis for applying to the competent court".

The implementation of the proposal contained in Thesis No. 5 would paralyze, above all, the legislative process. It should be noted that the wording of "all bills" was included in the title of Thesis No. 5, while the argumentation to this Thesis contained the wording "Bills, especially those relating to the own tasks of local government units". This argumentation does not reflect the content of the Thesis itself. It is difficult to judge whether this semantic procedure was intentional or accidental. However, one must bear in mind this internal contradiction.

Although the regulations in force in Poland are not inconsistent with the European Charter of Local Self-Government, it is worth adding that the Charter does not provide for an absolute obligation to consult "all bills" with the local government. According to Article 4 Section 6 of the Charter, local authorities shall, within the limits of the law, have full discretion to exercise their initiative with regard to any matter which is not excluded from their competence nor assigned to any other authority (Sobański, 2020).

Thesis No. $3^{2}$ of the Self-Governing Republic of Poland states as follows: "Transformation of the Senate of the Republic of Poland into a Self-Government Chamber". The implementation of the proposal contained in No. 3 would reduce the Senate to the role of an organ of selfgovernment. The powers of the Senate are strictly defined in the Constitution. According to the Article 95 Section 1 of the Constitution, legislative power in the Republic of Poland shall be exercised by the Sejm and the Senate. The Constitution vests legislative power in the Sejm and the Senate, executive power in the President and the Council of Ministers, and judicial power - in courts and tribunals. Thus the Sejm shares its legislative function with the Senate; simultaneously, it is part of the governmental system in Poland. The legislative competence of both Chambers is not symmetrical. The Constitution provides the Sejm with

\footnotetext{
1 Teza Nr 5

“Obowiązek konsultowania z przedstawicielami samorządu i społeczności lokalnej wszystkich projektów ustaw.

Projekty ustaw, szczególnie dotyczące zadań własnych jednostek samorządu terytorialnego, określonych w art. 166 Konstytucji RP, powinny podlegać obowiązkowej konsultacji z zrzeszeniami samorządów jako przedstawicielami wspólnot lokalnych. Wyniki tych konsultacji winny być umieszczane w ocenie skutków regulacji każdego projektu ustawy dotyczącej wspólnot lokalnych. Brak uzgodnienia stanowi podstawę do wystąpienia do właściwego sądu".

2 Teza Nr 3:

"Przekształcenie Senatu RP w Izbę Samorządową.

Przedstawiciele samorządu terytorialnego, samorządów zawodowych oraz organizacji pozarządowych powinni uzyskać reprezentację na szczeblu najwyższych władz państwowych i uczestniczyć aktywnie w tworzeniu regulacji prawnych. Należy znieść monopol partii politycznych w procesie stanowienia prawa w Polsce".
} 
a dominant role in the legislative process. However, the role the Senate in the legislative process is constitutionally guaranteed. It is worth noting that the Senate has the right to legislative initiative and participates in the adoption of laws.

The implementation of the proposal contained in No. 3 is not possible without making significant changes to the Constitution. Moreover, there is a clear relationship between the content of Thesis No. 3 and Thesis No. 5. Assigning some powers of the legislative authority to the self-government would involve the adoption of systemic solutions characteristic of the federal state. There is nothing to prevent the current representatives of self-government from running for the Senate. Their competences and credibility will be assessed by citizens by voting (Sobański, 2020).

Thesis No. $17^{3}$ states as follows: "Liquidation of the office of the voivode. Leaving the power to the central supervision over the legality of operations of local self-government units". The only one information found in Thesis No. 17 is: "Delegation of all tasks relating to local public affairs to the voivodeship self-government". The content of Thesis No. 17 implies the need to remind about the role and competences of the voivode as an authority. It should be emphasized that the voivode is a representative of the Council of Ministers in a voivodship, in charge of joint government administration. The voivode acts as the head of central government institutions at regional level. He fulfils the role of the overseeing officer for the territorial self governing bodies. He is a representative of the State Treasury, to the extent and on the principles set out in separate provisions. The powers of the voivode as a monocratic government administration body include all matters related to government administration, unless they have been reserved for other government administration bodies (Dobrowolski, 2018; Zawisza 2013). As a supervisory body over the activities of local government units, the voivode exercises control in terms of legality, with the proviso that the voivode controls the performance of government administration tasks by self-government bodies in terms of legality, efficiency and reliability. The voivode is appointed by the Prime Minister.

The Polish administrative system operates on three self-government tiers: voivodeship, poviat and gmina. The head of the self-government is a voivodeship marshal. The executive, headed by the marshal, drafts the budget and development strategies as well as manages the property of voivodeship. The marshal is elected by councillors from the provincial assembly.

As A. Kiełbasiński aptly notices, since the competences of voivodes go far beyond the supervision over local governments, the postulate of the Self-Governing Republic of Poland contained in Thesis No. 17 is largely political (Kiełbasiński, 2019). At the same time, the supervision based on the legality criterion means that the activity of local government is assessed in terms of compliance with legal acts. The institution of supervision over local government is one of the most important guarantees of the performance of public tasks by the local government within the framework and pursuant to the provisions of law. At the same time, the supervision determines the actual systemic position of the local selfgovernment, and also determines the direction and scope of decentralization (Kościelniak, 2012). According to the regulations contained in Article 171 of the Constitution, the organs

\footnotetext{
${ }^{3}$ Teza Nr 17:

"Likwidacja urzędu wojewody. Pozostawienie władzy centralnej nadzoru nad legalnością działania jednostek samorządu terytorialnego.

Przekazanie wszystkich zadań dotyczących spraw publicznych w regionie samorządowi województwa”.
} 
authorized to exercise supervision over local government are not only the voivode, but also: the Sejm, the Prime Minister (Kowalczyk, 2017).

When analyzing Theses No. 17 should also be related to the content of Thesis No. $1^{4}$, which reads as follows: "Full right of a self-governing community to independently decide on all local matters". Argumentation of Thesis No. 17 provides following information: "residents are the only supervisory authority for local self-governments". Although Polish legal regulations do not contradict the European Charter of Local Self-Government, it is worth noting that Art. 8 of the Charter directly assumes the existence of administrative control over the activities of local communities.

\section{FINAL REMARKS}

The implementation of proposals contained in Theses No. 3 and No. 5 carries the risk of systemic changes in Poland that could eliminate the principle of unitarity in favor of a federal system.

Apart from the landisation understood as the creation of a federal state system, which would be clearly contrary to the content of Art. 3 of the Constitution, it should be emphasized that any concept of decentralization would have to be carried out in a manner that would respect the "common good" of all citizens. Therefore, Theses No. 1 and No. 17 are in contrary to decentralization understood in this way.

The existing provisions concerning local self-government are consistent with the Constitution. On the other hand, the Constitution fully meets the conditions for territorial self-government adopted in the European Charter of Local Self-Government.

Referring to the German system, it is worth adding that in Chapter II of the Potsdam Agreement of August 2, 1945, a requirement was introduced to decentralize Germany both in economic and political sense. It had an impact on the content of Constitution of the Federal Republic of Germany (Jedynakiewicz-Mróz, 2012). The Constitution adopted by the Parliament was approved on May 8, 1949 by Commanders-In-Chief of the Western occupation zones. The Constitution contains the political principles of the Federal Republic of Germany, which include, among others, federalism. The decentralization of Germany through the introduction of the federal system was primarily aimed at weakening the state (Sobański, 2019; Sobański, 2020). These circumstances should also be taken into account when assessing the concept of systemic unitarity of the state in comparison to the federal system.

\section{REFERENCES}

Antkowiak P. (2012). Decentralizacja władzy publicznej w Polsce. Środkowoeuropejskie Studia Polityczne, 2, 155-174.

\footnotetext{
4 Teza Nr 1:

"Pełne prawo wspólnoty samorządowej do samodzielnego decydowania o całokształcie spraw lokalnych. Samorządy terytorialne powinny mieć pełną samodzielność: prawną, organizacyjną i majątkową w zakresie realizacji zadań własnych we współpracy i konsultacji z mieszkańcami. Jedynym organem nadzoru dla samorządów w kwestiach lokalnych są mieszkańcy, którzy powinni być jak najszerzej włączeni w proces współdecydowania o sprawach małych ojczyzn".
} 
Buczyński K., Jaworski J., Sosnowski P. (2016). Bariery rozwoju samorządu terytorialnego w Polsce z perspektywy 25 lat jego funkcjonowania. In S. Sagan \& M. Sitek (Eds.), Bariery, wyzwania i perspektywy przekształceń samorządu terytorialnego w Polsce (pp. 111-134). Wydawnictwo Wyższej Szkoły Gospodarki Euroregionalnej im. Alcide De Gasperi w Józefowie.

Buzek J. (2015). Samorządna Rzeczpospolita - 25 lat samorządu w Polsce. Ruch Prawniczy, Ekonomiczny i Socjologiczny, 3, 11-15.

Dąbrowski M. (2017). Domniemanie zgodności ustaw z Konstytucją Rzeczypospolitej Polskiej z 1997 roku.

Katedra Prawa Konstytucyjnego na Wydziale Prawa i Administracji UWM Olsztyn.

Dobrowolski Z. (2018). Administracja publiczna w Polsce. Zarządzanie. Zarys problematyki. Wydawnictwo E-Studio.

Jedynakiewicz-Mróz K. (2012), "Po owocach poznacie ich”. Niemieckie elity polityczne a powstanie RFN (1948-1949). Przegląd Nauk Historycznych, 1, 63-84.

Kiełbasiński A. (2019). 21 tez samorządowych nie zawsze dobrych dla biznesu. Warsaw Enterprise Institute. https://wei.org.pl/article/21-tez-samorzadowych-nie-zawsze-dobre-dla-biznesu/

Kieres L. (2015). Europejska karta samorządu lokalnego w orzecznictwie Trybunału Konstytucyjnego,

Ruch Prawniczy, Ekonomiczny i Socjologiczny, 3, 79-99.

Korczak J. (2016). Współdziałanie organów administracji rządowej i samorządowej w stanach nadzwyczajnych, LEX, Nr 313966/2.

Kościelniak G. (2012). Zmiany społeczne, gospodarcze i kulturowe w erze ponowoczesnej a ustrojowa przyszłość instytucji samorządu terytorialnego w Polsce. Państwo i Społeczeństwo, 3, 17-39.

Kowalczyk M. (2017). Zarządzenie zastępcze wojewody jako środek nadzoru nad samorządem terytorialnym. Zagadnienia teoretyczne i praktyczne. In M. Chrzanowski, J. Sobczak (Eds.), Samorządy w procesie decentralizacji władzy publicznej. (pp. 13-193). Wydawnictwo Muzyczne Polihymnia.

Lewandowski P. (2019). Tylko u nas! To się dzieje. Trwa pełzające rozbicie dzielnicowe, Polska Niepodległa. https://polskaniepodlegla.pl/opinie/item/20467-tylko-u-nas-to-sie-dzieje-trwa-pelzajace-rozbiciedzielnicowe

Litwin T. (2018). Pojęcie "przedstawiciela Narodu” w świetle art. 4 ust. 2 Konstytucji RP z 1997 r. Horyzonty Polityki, 9, 11-31.

Łączkowski W. (2018), Trójpodział władz a dobro wspólne, LEX, Nr 339140/1.

Mączyński M. (2015). Reforma ustroju samorządu terytorialnego: uwarunkowania, możliwości i konsekwencje zwiększenia samodzielności JST. In P. Kopyciński (Ed.), Sprawne państwo. Propozycje zmian w funkcjonowaniu jednostek samorządu terytorialnego w Polsce. Uniwersytet Ekonomiczny w Krakowie, Kraków 2015.

Patyra S. (2018). Samorząd terytorialny jako czynnik wzmacniający zasadę dobra wspólnego. Ruch Prawniczy, Ekonomiczny i Socjologiczny, 1, 231-239.

Patyra S. (2017). Zakres dopuszczalnej ingerencji władzy centralnej w sferę funkcjonowania samorządu terytorialnego w Polsce - refleksje aksjologiczne. M. Chrzanowski, J. Sobczak (Eds.), Samorządy w procesie decentralizacji władzy publicznej, M. Chrzanowski, J. Sobczak (red.), Wydawnictwo Muzyczne Polihymnia, Lublin 2017, s. 26.

Rachoń M. (2019). Więcej kasy w ręce ludzi Platformy, nawet kosztem likwidacji państwa. Niezależna. https://niezalezna.pl/283355-wiecej-kasy-w-rece-ludzi-platformy-nawet-kosztem-likwidacji-panstwa

Radziewicz P. (2015). Decentralizacja jako pojęcie prawne. Kwartalnik Prawa Publicznego, 12, 7-36.

Sobański P. (2019). Roszczenia Polski wobec RFN w świetle doktryny niemieckiej. Wydawnictwo Wyższej Szkoły Pedagogiki i Administracji im. Mieszka I w Poznaniu.

Sobański P. (2020). Wybrane aspekty prawne tzw. landyzacji Polski. Ceon.pl https://depot.ceon.pl/ bitstream/handle/123456789/17847/adwokat-Piotr-Sobanski-Zielona-Gora-Landyzacja-Polski-wybraneaspekty.pdf

Zawisza J. (2013). Rola administracji publicznej w kształtowaniu bezpieczeństwa państwa. In W. Brzęk, S. Ćmiel, K. Novikova (Eds.), Funkcjonowanie administracji publicznej - historia i stan obecny, (pp. 63-80) Wydawnictwo Wyższej Szkoły Gospodarki Euroregionalnej im. Alcide De Gasperi w Józefowie. 